\title{
13. How has the Chinese economy capitalised on the demographic dividend during the reform period?
}

\section{Cai Fang}

\section{Introduction}

China's unprecedented economic growth during the period of reform that began in the late 1970s has been accompanied by a dramatic demographic transitionnamely, a rapid decline in the fertility rate. In the period 1978-2015, China realised a real growth rate of gross national income (GNI) of 9.6 per cent- the fastest speed anywhere in the world in that period. On the other hand, according to the United Nations (UN 2015), China's total fertility rate (TFR) dropped from 2.5-3 in the late 1970s and early 1980s to a replacement level of 2 in the first half of the 1990s, and has remained constant at about 1.5 since the second half of the 1990s.

There has been debate among scholars and policymakers about the actual level of China's TFR. The results based directly on various censuses and 1 per cent population sampling surveys show an incredibly low TFR. For example, the rate was 1.22 according to the 2000 census, 1.34 according to a 2005 sampling survey, 1.19 in the 2010 census (Guo et al. 2014: 21) and 1.05 from a 2015 sampling survey (NBS 2016: 361). Even after data adjustment based on assumptions of statistical error, most scholars conclude that China's TFR remains at 1.4-a level lower than that published by the United Nations. ${ }^{1}$ The TFR increased moderately only after relaxation of government policy allowed couples to have two children.

An unquestionable truth is that China's TFR has stayed at a level significantly lower than the replacement level for a quarter of a century. Before it eventually brought about population ageing supposedly unfavourable to economic growth, this rapid demographic transition had helped form a population pattern characterised by a rapid increase in the working-age population and a decrease in the dependency ratio (the ratio of dependants to the working-age population) — what economists call the 'demographic dividend'. The contribution of the demographic dividend to economic growth has been recognised and documented in the economics literature (for example, Williamson 1997).

1 Guo et al. (2014) presented ample evidence of a very low TFR in present-day China. 
Researchers have examined the interplay between economic development and the demographic transition and estimated the contribution to growth of the population factor during China's reform period. For example, Wang and Mason (2008) find that the decline in the dependency ratio contributed 15 per cent to economic growth in the period 1982-2000, while Cai and Wang (2005) estimated the contribution of the dependency ratio was 26.8 per cent in the same period.

Let us consider a standard Cobb-Douglas production function (Equation 13.1).

\section{Equation 13.1}

$Y=A * F(K, L)=K^{\alpha} *(A L)^{1-\alpha}$

In Equation 13.1, $Y$ denotes output (for example, gross domestic product: GDP) growth; $K$ is physical capital input; $L$ is human capital input, which can be divided into the amount of labour and its educational attainment; and $A$ is total factor productivity (TFP), which can be decomposed into reallocative efficiency and a residual. In addition, some economists, acting as 'right-hand warriors' (Srinivasan and Bhagwati 1999), add into a growth regression dozens of explanatory variables that are considered both theoretically possible and statistically significant. The population dependency ratio as a proxy for the demographic dividend is one such variable.

Broadly defining the demographic dividend as a contributor to economic growth, however, requires looking into almost all variables in the right-hand side of a production function equation, while the contribution of the dependency ratio as a variable to economic growth is, at most, a residual of the demographic dividend.

Based on the experiences of China and other East Asian economies and drawing on the dual economy theory developed by Lewis (1954), we can extend the ability of the neoclassical theory of growth to explain broadly defined demographic dividend in economic growth. In what follows, I explain the relevance of growth factors to demographics and reveal broadly defined demographic dividends gained in China's transition, which can be supported by existing research.

First, the fact that a low and declining dependency ratio helps create a high savings rate, on the one hand, and that unlimited labour supply delays the phenomenon of diminishing returns to capital, on the other, makes capital accumulation the main engine of economic growth. In an early study of China, the World Bank (1998) found that capital accumulation accounted for 37 per cent of GDP growth in the period 1978-95. Covering a much longer period, Cai and Zhao (2012) estimated the contribution of capital accumulation to be double this amount. More recent research suggests that labour productivity enhancement was a significant driver of 
economic growth during the reform period (for example, IMF 2006; Zhu 2012), whereas, among the factors that increase labour productivity, capital deepening or the capital-labour ratio play a major, and increasing, role (IMF 2006; Kuijs 2010).

Some economists have criticised growth in which capital plays the overwhelming role, believing it is not much of a miracle and is not sustainable (for example, Young 2003; Krugman 2013). As the experiences of China and other East Asian economies show, however, in the Lewisian-type dual economy development stage, unlimited labour supply can prevent the phenomenon of a diminishing return to capital for a certain period. For example, research findings suggest that during most of China's reform period, the return to capital investment remained extraordinarily high (Bai et al. 2006) and, after the Lewis turning point—characterised by a labour shortage and wage inflation-returns to capital have rapidly diminished (Bai and Zhang 2014). This proves that the contribution of capital to growth is indeed part of the demographic dividend.

Second, advantageous population factors guarantee the size and quality of the labour force are sufficient to make a significant contribution to economic growth. Sufficient supply of labour has been widely recognised as a favourable factor in catch-up growth. What is often neglected is that the improvement of human capital in less-developed countries overwhelmingly relies on a favourable population age structure that ensures a steady flow of new entrants with increased years of schooling to the labour market.

According to the World Bank (1998), the estimated contribution to GDP growth of labour inputs, measured in terms of both quantity and quality, was 17 per cent, while Cai and Zhao (2012) estimated labour's contribution to be 8 per cent and that of human capital 4 per cent. By adding together the effects of the number of years of workers' schooling and the effects of education on productivity, Whalley and Zhao (2010) estimated the direct and indirect contribution of human capital to be as high as 38 per cent.

Third, labour mobility between rural and urban areas, among sectors and among regions following the direction from low to high productivity brings about an increase in the reallocative efficiency of resources, which is a significant part of TFP growth.

By decomposing sources of TFP growth in China into the reallocative efficiency of resources and a residual, the World Bank (1998) found that the formernamely, productivity growth as a result of labour mobility from low-productivity sectors (labour-surplus agriculture and labour-redundant state-owned enterprises $(\mathrm{SOEs})$ ) to high-productivity sectors (nonagricultural sectors and newly established enterprises)-contributed to 16 per cent of the growth in GDP in the period 1978-95. Cai and Wang (1999) found that labour transfers from agricultural to 
nonagricultural sectors were responsible for the overwhelming part of TFP growth and contributed 21 per cent to per capita GDP growth in the period 1978-98. In a more recent study, Zhu (2012) found that the sound performance of China's TFP in the period 1978-2007 can be attributed to the rapid expansion and productivity growth of nonstate enterprises.

Finally, for any country, increasing population size tends to intensify demand for and supply of innovation, which will fuel economic growth through speeding up technological progress and increasing TFP. This argument, put forward by growth theorists and economic historians, has been tested empirically (for example, Jones 2002). To my knowledge, however, there has not been any empirical study concerning modern China.

A population structure that is theoretically favourable for economic growth will not, however, be spontaneously translated into a demographic dividend-that is, a realistic driver of growth. In fact, the economic performance of many countries experiencing a similar demographic transition cannot rival that of China.

According to the World Bank and the International Monetary Fund (IMF) (2016: 268-73), countries with a TFR higher than a replacement level of 2.1 in 1985 and a working-age population that is declining or static in the period 2015-30 can be categorised as 'late-dividend economies', of which China is one of 54 such economies. In the period 1978-2015, China realised an annual growth rate of per capita GNI of 9.73 per cent, compared with the arithmetical average of 3.77 per cent in the 44 other economies with available data. Even taking into account a convergence effect-that is, observing the poorest countries in the latedividend category that are supposed to have a potential similar to China's to grow faster-China stands out in terms of economic growth.

Generally speaking, reforms aimed at ameliorating key obstacles to economic growth could accelerate growth in the absence of conditions that are widely seen as essential for development. ${ }^{2}$ For China in particular, its outstanding growth performance has been the result of its implementation of reform and opening-up, cashing in on the advantageous growth conditions. China has translated its demographic dividend into a high potential growth rate and ultimately realised unprecedented actual growth by improving incentive mechanisms in micro-management, getting prices right, developing factor markets, eliminating institutional barriers to mobility of production factors and embracing global markets, technology and competition.

The rest of this chapter is organised as follows. It first provides a retrospective of the formation of population policy, its impacts and the process of adjustment, showing that the demographic transition was a result of not only population

2 This proposition is credited to Hollis Chenery. See Brandt and Rawski (2008: 9). 
policy, but also economic and social development. It then looks at how reforms in related areas released surplus labour from agriculture and expanded employment in nonagricultural sectors. It further empirically tests the effects of labour reallocation on labour productivity improvement and thus on economic growth. Finally, based on the prospect of future population change, it draws policy implications for further reform.

\section{Population policy and the demographic transition}

As early as the 1950s, China's top decision-makers began to note the country's mushrooming population, even though Professor Ma Yinchu's views on population and his proposals for birth control were severely criticised by his fellow scholars and political leaders (including chairman Mao Zedong). China's first population census was conducted in 1953; however, no decision was made on concrete policy measures at that time. It was only after the failure of the Great Leap Forward and the bitter experiences of the Great Famine in the late 1950s and early 1960s that Chinese leaders decided to take action to check the population boom.

By the end of 1962, the central government was advocating implementation of family planning to mitigate the momentum of population growth. In 1970, it officially incorporated the issue of population into the national economic development plan, but it was not until 1980 that the Chinese Government formally announced the one-child policy. Reading the official terms of the proposal publicised in 1988that is, advocacy of late marriage and late childbearing, having fewer children and better child care and one child per couple-family planning did not appear to be compulsory. In reality, the word 'advocacy' here should be read to mean 'mandatory requirement'. In the 1990s, population regulations focusing on implementing the one-child policy had been successively approved by all provincial people's congresses (the local legislatures) and implemented by provincial governments.

It is not accurate, however, to regard the family planning policy in place in China for more than three decades as simply a 'one-child policy'. After a lengthy evolution, the structure of the policy package in 2010 could be described as comprising: 1) the one-child policy, which was applied to all urban and rural residents in six provinces, covering 35.9 per cent of China's total population; 2) the one-and-a-half child policy, under which rural couples whose first child is a girl were allowed to have a second child, and which covered rural residents in 19 provinces, accounting for 52.9 per cent of the total population; 3 ) the two-child policy, which was applicable to rural residents in five provinces and covered 9.6 per cent of the population; and 4) the three-child policy, which was applied to farmers and herdsmen of ethnic minorities in some areas and covered 1.6 per cent of the total population. 
In addition, in the Tibetan Autonomous Region, urbanites were allowed to have two children and there were no restrictions on the number of children for farmers and herdsmen of Tibetan and other ethnic minorities with very small population size (see CDRF 2014: Ch. 4).

The strictness of the implementation of the family planning policy was not immutable. First, the policy was introduced at the same time as the initiation of China's market-oriented reforms and resulting economic growth. While adhering to the population control target, implementation has been directed more and more towards promotion of the economy, poverty alleviation, family development, social governance and economic incentives. Second, some provinces relaxed the restrictions quite some time ago-for example, permitting urban couples, both of whom were an only-child, and rural couples, one of whom was an only child, to have two children. More fundamental family planning reforms have been successively carried out - in 2014 allowing couples, one of whom was an only child, and, then in 2016, all couples to have two children.

In any country, economic growth and social development are the drivers of demographic transition. In China's case, its unique family planning policy is only an additional, and diminishing, driver. By examining three theoretical factors that are expected to have an effect on reducing the fertility rate - that is, implementation of population policy, increasing per capita GDP and human capital improvementand regressing them as explanatory variables, $\mathrm{Du}$ (2005) found that all significantly contributed to lowering the fertility rate during the first decade of China's reforms, and that the effect of the policy variable disappeared, while that of the income and human capital variables remained in the second decade of reform.

To a reasonable extent, it is the outstanding performance of China's economic growth and social development that brought its TFR to below replacement level in the early 1990s, and kept it there since. As a result, natural population growth has dramatically slowed. In this, China has followed the universal law of demographic transition. What is unique about China's experience is that it took just 30 years or so for the country to complete its transition from a high-fertility to a low-fertility rate. In comparison, Western countries have taken more than twice as long to complete the transition. What is more, China entered its low-fertility phase much earlier than other developing countries with similar per capita income levels, which characterises it as a country that is 'growing old before getting rich'.

Figure 13.1 shows the changes in birth and mortality rates and their differencenamely, the natural population growth rate-since the founding of the People's Republic of China (PRC). If the abnormal decline in the birth rate, the rise in mortality and the subsequent enormous drop in the natural growth rate in the late 1950 s and early 1960s are considered an external shock and their impacts on the 
overall, long-term trend are eliminated, one can conclude that China's population change in the past nearly seven decades has followed the general trajectory experienced in the pioneering countries.

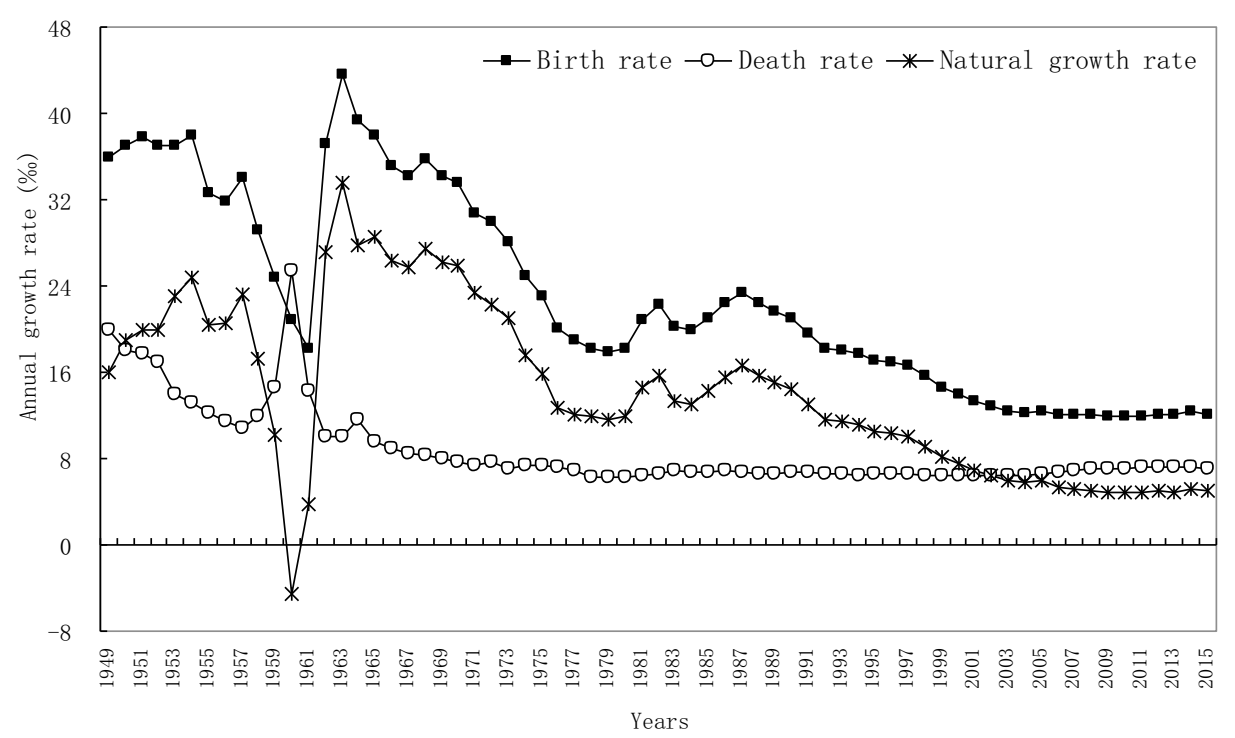

Figure 13.1 Birth rate, death rate and natural growth rate of population in China

Sources: NBS (various years).

Before the mid-1960s, the sharp fall in the mortality rate and lagging response in the birth rate resulted in a rise of population growth. This 'baby-boom' aroused concerns in academic circles and among decision-makers, because no one at the time could foresee a fall in fertility. ${ }^{3}$ During the 1970s, while the death rate continued to decline_-although at a relatively slower pace — the birth rate also began to decline substantially, which brought about a sharp plunge in the natural population growth rate. Then came an era in which the mortality rate remained all but unchanged and, consequently, the birth rate and natural growth rate moved synchronously. They rebounded for a couple of years in the 1980s and then dropped again in the 1990s. China's natural population growth rate was always at a level of fewer than 10 per 1,000 after 1998 and has been lower than 6 per 1,000 since 2004 .

As expected, such changes in fertility and population growth rates have altered the age structure of China's population. According to data released by the United Nations (2015), the Chinese working-age population (those aged between 15 and

3 It is commonly believed that Notestein (1945) coined the theory of demographic transition, as he was the first to provide a standard theoretical explanation for the decline in fertility being an inevitable stage of the demographic transition. There was no way for academics such as Ma Yinchu and decision-makers such as Mao Zedong to know such a theory stylised from global experiences. 
59) increased from 373 million in 1965 to a peak of 941 million in 2010 , while the dependency ratio calculated on this definition fell from 0.89 to a low of 0.43 in the same period.

That is, China enjoyed its most productive population structure in the period between the mid-1960s and 2010 and, within that, the period of economic reform - 1978 to 2010 — can be considered the population window of opportunity, or demographic dividend. The year 2010 is therefore an obvious turning point. As the working-age population declined and the dependency ratio increased after that time, the demographic dividend that spurred the high growth rate of the Chinese economy has been rapidly disappearing. If the population trend remains unchanged, it is predicted the working-age population will drop to 674 million and the dependency ratio will increase to nearly 1 by 2050 (UN 2015).

\section{How has reform promoted employment?}

In economic history, a situation in which a massive surplus of agricultural labour cannot be transferred to nonagricultural sectors through development of a dual economy (Lewis 1954) is sometimes called agricultural involution, which impedes labour productivity improvement in agriculture and delays industrialisation (see Huang 2002). In such a case, the advantageous population structure will not translate into a demographic dividend, and will instead become a population burden. The same goes with the 'iron rice bowl' and overstaffing in SOEs caused by planned assignment of jobs in urban areas depress efficiencies of enterprise management and resources allocation.

Given that full and efficient utilisation of abundant labour are preconditions for translating favourable population properties into factors that actually spur economic growth, it is necessary to examine how reform helped to promote employment and the reallocation of labour, to understand how China cashed in on the demographic dividend during the reform period.

Reforms that are conducive to the movement and reallocation of production factors in general, and of the labour force in particular, include many at both micro and macro levels. Overall, the economic growth spurred by reform has created plenty of jobs, and the elimination of institutional barriers through deregulation has motivated labourers-following market signals of employment opportunity and relative income-to leave low-productivity jobs, migrate among regions and sectors and take new high-productivity jobs. Therefore, by examining how migrant labourers have obtained rights of exit, mobility and entry, we can concisely document the processes of related reforms and their effects. 
First, rural reforms released surplus labour. The introduction of the household responsibility system (HRS) was a critical reform that granted farmers the right to exit agricultural work with very low marginal labour productivity. Even before the system was officially implemented in 1978, the HRS was secretly piloted in some remote rural villages. After the third plenum of the eleventh Central Committee of the Communist Party (CCCP), which was convened in 1978, the government accepted, and eventually encouraged, the HRS, which became a symbol of the beginning of economic reform.

By the end of 1984, all production brigades and 98 per cent of households in rural China had adopted the HRS and the people's commune system was abolished. The original motive of the reform was to improve incentives for agricultural production by granting farmers autonomy of operation and rights of residual claimants. An unexpected outcome was that rural households have since obtained autonomy in owning and allocating factors of production.

Under the commune system, employment was confined to farming and, in many cases, solely to grain production; workplaces were restricted to production brigades in the home village and each brigade determined the hours of labour-all of which served to maintain patterns of resource misallocation. Under the HRS, once households had paid agricultural tax, met the state's procurement targets and turned over the collective retention, they had autonomy to decide which crops to plant and how to allocate their work time. With this autonomy, once the labour surplus became overt, farmers began to reallocate their labour and other factors of production.

Reforms also promoted labour mobility among sectors and between regions. Under the planned system, a troika of institutional arrangements- the commune system, the household registration (or hukou) system and the rationing of major agricultural products-had severely restricted labour mobility between sectors and regions. As incentives improved and labour efficiency increased, a labour surplus in agriculture appeared. One study (Taylor 1993) shows that, in the mid-1980s, surplus labour amounted to 100 to 150 million workers, accounting for 30 to 40 per cent of the total workforce. As institutional barriers were eliminated, surplus labourers began to move away from their previous areas of employment.

This labour transfer led successively to movement away from grain production alone to diversified farming; from farming to broadly defined agricultural sectors, including farming, forestry, animal husbandry, fishing and business sidelines; from agriculture to rural industries (township and village enterprises, or TVEs); and from rural nonagricultural work to urban employment. 
There have been several breakthroughs in the reallocation of rural labour. First, with the abolition of the commune system and substantial enhancement of farm products, farmers were permitted to transport and sell their own farm products beyond their hometown-for the first time breaking the geographic restrictions on farmers' employment. Second, farmers were allowed to work in neighbouring towns (by providing their own rations), which, for the first time, broke the employment boundary between rural and urban sectors. In the early 1990s, with the abolition of the rationing system, there were no longer any practical obstacles to rural labourers working and living in cities.

Although the hukou system still segments the provision of public services according to residential identity — preventing migrant workers and their accompanying family members from equal access to compulsory education, basic social security programs, the minimum living guarantee program and subsidised housing - it no longer serves as an obstacle to labour mobility and population migration. In that sense, there has been a real breakthrough in reform of the hukou system.

Third, reforms break barriers deterring labour from entering high-productivity sectors. When the labour market was undeveloped and divided between rural and urban employment, labourers leaving agriculture could find only marginal jobs in nonagricultural sectors. For example, until the 1980s, TVEs absorbed the majority of labourers exiting agriculture. After 1992, the rapidly expanding labour-intensive manufacturing and nonpublic sectors in coastal regions began absorbing massive numbers of cross-regional migrant workers, creating the first wave of internal migration. In the late 1990s, radical reform of the employment system in SOEs began to link up rural and urban labour markets. As a result, barriers to labour mobility across regions and across sectors have been gradually eliminated.

Fourth, reforms create jobs and reallocate labour to urban sectors. The entry of new workers to the labour market and the relocation of those unemployed and laid-off in urban areas have followed a pattern similar to that of the transfer of surplus rural labour. Reforms carried out as early as the 1980s granted SOEs autonomy in hiring and firing — on paper. Managers, however, were not encouraged to use this autonomy, because the undeveloped labour market and imperfect social security system would have been unable to cope with the potential lay-offs. At the time, there was a lack of employment opportunities outside SOEs and no unemployment insurance system to protect any laid-off workers.

In the late 1990s, severe operational pressures in SOEs forced reform that was characterised by ending the longstanding concept of the 'iron rice bowl' and laying off redundant workers. This was the tipping point for reform of the urban employment system. First, to secure a basic living for laid-off workers, unemployment insurance and other social security programs were established. Second, workers were reemployed through the newly-developed labour market with the assistance of the 
government's proactive employment policy. Third, migrant workers were given more equal opportunities to compete with urban workers in the labour market, which activated an adjustment of labour stocks in urban sectors.

Finally, participation in the global division of labour expands aggregate employment. One of the important factors that allows China to cash in on its demographic dividend is the expansion of labour-intensive manufacturing, which has absorbed large numbers of migrant workers and gained a huge share of international commodity markets. This is what makes the Chinese experience so outstanding in the course of economic globalisation.

By analysing employment growth and its composition in the United States, Spence and Hlatshwayo (2011) show that, as a result of the massive transfer of manufacturing abroad, jobs in this sector were lost, with almost all of the new increment in employment coming from nontradable sectors in the period 19902008. They imply that offshoring destroyed the US economy. Taking the US case as a reference, we examine the expansion of China's nonagricultural employment.

Based on data from Chinese economic censuses conducted in 2004, 2008 and 2013, and using a similar categorisation method to Spence and Hlatshwayo (2011), we classify China's nonagricultural employment on the basis of corporate units in the censuses in the tradable and nontradable sectors, with a special focus on manufacturing and construction, which took the lion's share of employment in the two sectors, respectively. The total expansion and structural change of employment of those categories in the period examined are shown in Figure 13.2.

As shown in Figure 13.2, nonagricultural employment in urban and rural China expanded at an annual growth rate of 5.9 per cent in 2004-13, totalling 352 million workers in 2013. Growth in the tradable and nontradable sectors was also relatively balanced, with an annual growth rate of 6.9 per cent for the tradable sector and 4.7 per cent for the nontradable sector. As these levels are based on reporting from corporate units, real nonagricultural employment and its expansion in the period examined are likely greatly underreported. In what follows, by comparing different sources of statistics, we can examine the degree to which the actual level of employment differs from the census data. 


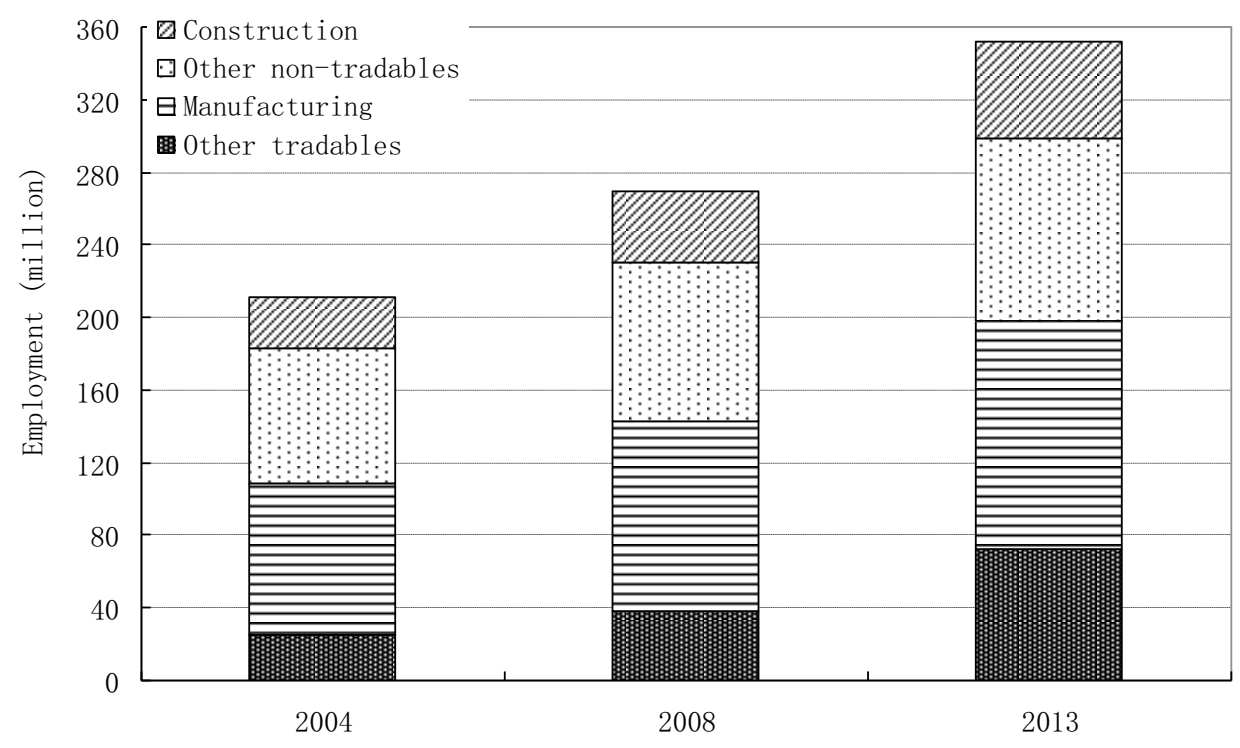

Figure 13.2 Expansion and composition of nonagricultural employment

Sources: Data from first, second and third economic censuses, NBS official website: www.stats.gov.cn.

The official statistics for urban employment collected yearly are based on 'establishments' rather than 'corporate units', generating a much greater amount of nonagricultural employment. According to these data, urban employment amounted to 178 million workers in 2015. By including employment in private enterprises and self-employment, the figure for urban employment increases to 368 million.

In addition, most temporary employees and dispatched labourers-many of whom are migrant workers - are not reported by enterprises and are therefore missing from the statistics. Therefore, the household-based survey conducted in accordance with the definitions of the International Labour Organization (ILO) shows an even larger number for urban employment, of 404 million. The difference between this survey data and the preceding data can be viewed as urban informal employment.

Even this number omits some migrant workers in urban sectors. A rough estimate shows that about 20 million migrant workers were excluded from the urban employment statistics (see Cai et al. 2016). If these migrant workers were also included in the statistics, total urban employment could be as high as 424 million in 2015. 


\section{Labour reallocation effects}

As Kuznets (1957) points out, the essential aim of structural change is to reallocate factors of production (especially labour) from low-productivity sectors to highproductivity sectors, and therefore to increase the allocative efficiency of resources. Based on the experiences in East Asia (mainly China, Japan and Korea), Aoki (2012) identifies a unique stage of development led by structural transformation and called the K(uznets)-phase. Other researchers find that labour transfers to gain reallocative efficiency characterise the typical process of structural change in Asian economies (McMillan and Rodrik 2011), explain an important part of TFP, and thus labour productivity growth in China (Bosworth and Collins 2007), and contribute significantly to the growth of the Chinese economy as a whole (Du 2014).

In China, reforms have eliminated a host of institutional barriers to labour mobility and spurred labour reallocation from low-productivity sectors and regions to highproductivity sectors and regions. Such a Kuznets process has increased resource allocation efficiency, contributing to the improvement of TFP and supporting outstanding economic growth. That is, the demographic dividend has been embodied in both economic growth and structural changes in China during the reform period. The resource reallocation effects can be empirically examined as follows.

General experiences of economic development suggest that the agricultural share in output and employment declines over time as a result of an increase in a country's income level. After 40 years of economic development and demographic transition, total employment in China expanded from 402 million in 1978 to 775 million in 2015. Meanwhile, as a result of the large-scale transfer of agricultural labour, according to officially published data, the share of labour in the primary sector declined from 70.5 per cent to 28.3 per cent, while the share of labour increased from 17.3 per cent to 29.3 per cent in the secondary sector and from 12.2 per cent to 42.4 per cent in the tertiary sector.

As some researchers have argued, the official data likely overstate the size and share of agricultural labour (see Rawski and Mead 1998; Cai et al. 2013). Recalculations by Cai (2017) show the share of labour actually engaged in agriculture in 2015 is 18.3 per cent, and the corresponding share of labour in secondary and tertiary sectors is 33.4 per cent and 48.3 per cent, respectively. That is, the actual share of agricultural labour is at least 10 percentage points lower than indicated in the official data. Table 13.1 compares the shares of labour by sector between different data sources for China and the average levels of global and country groups by income level. 
Table 13.1 International comparisons of labour distribution by sector (per cent)

\begin{tabular}{|l|r|r|r|}
\hline Countries and regions & Primary sector & Secondary sector & Tertiary sector \\
\hline China (official data) & 28.3 & 29.3 & 42.4 \\
\hline China (adjusted data) & 18.3 & 33.4 & 48.3 \\
\hline China (ILO data) & 28.9 & 23.7 & 47.3 \\
\hline World average & 29.5 & 21.5 & 48.9 \\
\hline Low-income countries & 68.5 & 8.3 & 23.2 \\
\hline Low-middle-income countries & 40.4 & 21.3 & 38.3 \\
\hline Upper-middle-income countries & 23.9 & 24.0 & 52.1 \\
\hline High-income countries & 3.1 & 22.5 & 74.3 \\
\hline High-income economies in East Asia & 4.1 & 35.3 & 60.3 \\
\hline
\end{tabular}

Note: The first line shows figures from official Chinese statistics, those in the second line are the author's estimates and the remainder are cited from ILO model estimations. Figures for the average levels of the world and economy groups are calculated as arithmetical means.

Sources: NBS (various years); ILO (2017); and author's estimations.

The official data suggest that China's labour distribution among sectors deviates from the international experience-in particular, through its larger share of agricultural labour and smaller share of service labour. The recalculated data are in line with what would be expected according to the economic growth and structural adjustment in China after three decades of reform. The share of agricultural labour, based on the recalculated data, is lower than the average level for upper-middleincome countries and substantially higher compared with the average levels for high-income economies.

China reached a per capita GNI of US\$7,900 in 2015 and is approaching the transition from upper-middle- to high-income status. According to the World Bank's classifications, there are 13 countries that have relevance to China and for which data are available for comparative purposes. They range from Gabon, with per capita GNI of US\$9,200 (similar to China's current level), to Croatia, with US\$12,760 (close to the transitional threshold of US\$12,600). In 2015, the arithmetical average share of agricultural labour of the 13 comparator countries was 12.8 per cent (ILO 2017) — that is, during the transition from its current status to high-income status, China will have to close the gap with those countries in terms of the sectoral distribution of labour.

We are now in a position to investigate the contribution of labour reallocation to labour productivity growth. In the period 1978-2015, according to calculations based on official data, China's labour productivity (GDP per worker in real terms) increased by 16.7 times: labour productivity in the primary sector increased by 5.5 times, in the secondary sector it increased by 13.5 times and in the tertiary sector, by 5.2 times. The calculations based on the adjusted data show a similar trend, but with a greater increase in labour productivity in the primary sector. 
By adopting methods used to decompose sources of labour productivity growth proposed by Timmer and Szirmai (2000) and Bosworth and Collins (2007), Cai (2017) estimates the functional and structural factors contributing to labour productivity growth in China's reform period. The results are shown in Table 13.2.

Table 13.2 Labour productivity growth and contributing factors in China (per cent)

\begin{tabular}{|l|r|r|r|r|r|}
\hline & \multicolumn{5}{|c|}{ Decomposition 1, based on Timmer and Szirmai (2000) } \\
\cline { 2 - 6 } & Total growth & $\begin{array}{c}\text { Contribution of } \\
\text { sectors }\end{array}$ & $\begin{array}{c}\text { Structural } \\
\text { effects }\end{array}$ & $\begin{array}{c}\text { Of which: } \\
\text { Static effect }\end{array}$ & Dynamic effect \\
\hline 1978-2015 & $1,671.3$ & 55.1 & 44.9 & 4.6 & 40.2 \\
\cline { 2 - 6 } & $(1,671.3)$ & $(56.0)$ & $(44.0)$ & $(5.5)$ & $(38.6)$ \\
\hline $1978-1990$ & 77.5 & 60.8 & 39.2 & 25.8 & 13.4 \\
\hline $1991-2003$ & 205.2 & 86.2 & 13.8 & 7.0 & 6.8 \\
\hline $2004-2015$ & 173.5 & 66.9 & 33.1 & 15.9 & 17.2 \\
\hline
\end{tabular}

\begin{tabular}{|l|r|r|r|r|r|}
\hline & \multicolumn{5}{|c|}{ Decomposition 2, based on Bosworth and Collins (2007) } \\
\cline { 2 - 6 } & Annual growth & Primary sector & $\begin{array}{c}\text { Secondary } \\
\text { sector }\end{array}$ & Tertiary sector & $\begin{array}{c}\text { Sectoral } \\
\text { reallocation }\end{array}$ \\
\hline 1978-2015 & 8.08 & 17.73 & 44.22 & 15.39 & 22.66 \\
\cline { 2 - 6 } & $(8.08)$ & $(21.86)$ & $(42.53)$ & $(14.53)$ & $(21.08)$ \\
\hline $1978-1990$ & 4.90 & 15.65 & 34.46 & 16.57 & 33.32 \\
\hline $1991-2003$ & 9.75 & 7.44 & 61.30 & 16.71 & 14.55 \\
\hline $2004-2015$ & 9.58 & 6.68 & 48.69 & 20.27 & 24.36 \\
\hline
\end{tabular}

Note: Figures in parentheses indicate results based on adjusted data.

Source: Cai (2017).

The decomposition results based on the method of Timmer and Szirmai (2000) show that, in the period 1978-2015, labour productivity growth in the Chinese economy as a whole can be attributed to sectoral contributions ( 55 per cent) and contributions from structural change ( 45 per cent). Of the latter, the contribution of the static shift effect, generated by a shift of labour towards sectors with a higher labour productivity level at the beginning of the period examined, was minor and the contribution of the dynamic effect, generated by a shift of labour towards sectors with higher labour productivity growth rates, dominated.

While the same decomposition is used to examine the periods 1978-90, 19912003 and 2004-15, the results show that structural effects were significant in the first and third periods, while sectoral contributions overwhelmingly dominated labour productivity growth in the second period. The static effect was significant in the second period, contributing 25.8 per cent to total labour productivity growth. 
From the decomposition based on the method of Bosworth and Collins (2007), one can see that yearly growth in total labour productivity was relatively slow in the first period and then substantially accelerated in the second and third periods. Across the entire period, the contribution of the primary sector steadily decreased and the secondary sector served as a major contributor to total labour productivity growth. In the second period, the contribution of labour reallocation was relatively small.

\section{Conclusion and future prospects}

During most of its period of economic reform, China experienced a dual economy pattern of development similar to that described by Arthur Lewis (1954) in his monumental paper. In such a pattern, the elimination of institutional obstacles preventing sufficient accumulation and efficient allocation of factors of production translated the demographic dividend and thus potential growth into unprecedented economic growth. That is, a favourable population structure helped China create the necessary conditions for high potential growth characterised by a high savings rate, sufficient supply of labour, rapid improvement of human capital and radical resource reallocation through labour mobility.

As the demographic transition has entered a new stage, traditional sources of growth tend to be exhausted. First, the negative growth in the working-age and economically active populations has led to and is aggravating the labour shortage, weakening the comparative advantage of China's industry. Second, the rapid increase in the capital-labour ratio has resulted in diminishing returns to capital. Third, the slower growth in the number of new entrants to the labour market has slowed the rate of human capital improvement. Finally, ageing of the rural population has retarded urbanisation and thus diminished the momentum of labour reallocation in enhancing labour productivity.

All these changes point to the rapid disappearance of the demographic dividend, leading to a decline in the potential growth rate. The estimates of Cai and Lu (2013) show China's potential growth rate reduced from about 10 per cent in the period before 2010 to 7.6 per cent during the period of the twelfth Five-Year Plan (2011-15) and 6.2 per cent during the thirteenth Five-Year Plan (2016-20). The actual growth rate and the pace of its slowdown have so far followed this predicted trajectory.

As is predicted by the theory of growth and the experiences of other economies, in the transition from middle-income status to high-income status_-an analogue to the transformation from a dual economy to the stage of neoclassical growth in most other cases-countries' growth rates inevitably and significantly slow (see Eichengreen et al. 2011; Barro 2016). The speed and degree of economic slowdown, 
however, vary from country to country, leading to different consequences in the long run (Eichengreen et al. 2013). For China, there are potentials it could tap into to help it avoid falling into the so-called middle-income trap.

The first is to maintain the traditional momentum of economic growth. There is still huge potential for China to narrow the gap with developed countries in its share of agricultural labour. Pushing through the unfinished reform of the hukou systemtransforming migrants from guest workers to legitimate residents in urban areaswill greatly enhance labour participation in nonagricultural sectors and therefore resource reallocative efficiency. The gap in workers' levels of human capital between China and the developed countries can also be narrowed by reforming the system of education and training to extend the average years of schooling and improve the quality of education. Reforms in a series of areas will create a better policy environment for small and medium-sized enterprises and strengthen competition to prevent diminishing returns to capital.

Second is to tap into sustainable drivers of economic growth by improving TFP. As the capacity to reallocate resources between the agricultural and nonagricultural sectors reduces, the reallocation of resources among nonagricultural industries and enterprises within narrowly defined industries will provide a new source of reallocative efficiency - as long as there are differences in productivity among them. Reforms aimed at creating a level playing field and a mechanism for 'creative destruction'-for example, in the financial sector and among SOEs-could create sustained sources of long-term growth.

Liu Xiang, a scholar of the Western Han Dynasty (77-6 BC), said that 90 miles is only half of a hundred-mile journey. For the 'great rejuvenation' of the Chinese nation proposed by the eighteenth National Congress of the Communist Party of China in 2012 - that is, becoming a modernised country by 2050-the past 40 years of reform indeed mark the halfway point to the final destination. Judging from past experiences and the potential of the reform dividend, reform and openingup will remain immense sources of economic growth for China. The purpose of looking back at the past 40 years of reform is to push the remaining necessary reforms to a new level.

\section{References}

Aoki, M. (2012), The five phases of economic development and institutional evolution in China, Japan, and Korea, in M. Masahiko, T. Kuran and G. Roland (eds), Institutions and Comparative Economic Development, Basingstoke, UK: Palgrave Macmillan. doi.org/10.1057/9781137034014_2. 
Bai, C.-E. and Zhang, Q. (2014), The rates of return to capital and the analysis of the determinants, The World Economy (10): 3-30.

Bai, C.-E., Hsieh, C.-T. and Qian, Y. (2006), The return to capital in China, NBER Working Papers No. 12755, Cambridge, MA: National Bureau of Economic Research.

Barro, R. J. (2016), Economic growth and convergence, applied especially to China, NBER Working Papers No. 21872, Cambridge, MA: National Bureau of Economic Research.

Bosworth, B. and Collins, S. (2007), Accounting for growth: Comparing China and India, NBER Working Papers No. 12943, Cambridge, MA: National Bureau of Economic Research.

Brandt, L. and Rawski, T. G. (2008), China's great economic transformation, in L. Brandt and T. G. Rawski (eds), China's Great Economic Transformation, Cambridge: Cambridge University Press.

Cai, F. (2017), Reform effects in China: A perspective of labor reallocation, Economic Research Journal (7): 4-17.

Cai, F. and Lu, Y. (2013), The end of China's demographic dividend: The perspective of potential GDP growth, in R. Garnaut, F. Cai and L. Song (eds), China: A new model for growth and development, Canberra: ANU E Press.

Cai, F. and Wang, D. (1999), The sustainability of economic growth and the labor contribution, Economic Research Journal (10): 62-8.

Cai, F. and Wang, D. (2005), China's demographic transition: Implications for growth, in R. Garnaut and L. Song (eds), The China Boom and Its Discontents, Canberra: Asia Pacific Press.

Cai, F. and Zhao, W. (2012), When demographic dividend disappears: Growth sustainability of China, in M. Aoki and J. Wu (eds), The Chinese Economy: A new transition, Basingstoke, UK: Palgrave Macmillan.

Cai, F., Du, Y. and Wang, M. (2013), Demystify the labor statistics in China, China Economic Journal 6(2-3): 123-33.

Cai, F., Guo, Z. and Wang, M. (2016), New urbanisation as a driver of China's growth, in L. Song, R. Garnaut, F. Cai and L. Johnston (eds), China's New Sources of Economic Growth. Volume 1: Reform, resources, and climate change, Canberra: ANU Press.

China Development Research Foundation (CDRF) (2014), Demographic Developments in China, London: Routledge. 
Du, Y. (2005), The formation of low fertility and its impacts on long term economic growth in China, World Economy (12): 14-23.

Du, Y. (2014), Labor market changes and the new economic growth, China Opening Journal (3): 31-5.

Eichengreen, B., Park, D. and Shin, K. (2011), When fast growing economies slow down: International evidence and implications for China, NBER Working Papers No. 16919, Cambridge, MA: National Bureau of Economic Research.

Eichengreen, B., Park, D. and Shin, K. (2013), Growth slowdowns redux: New evidence on the middle-income trap, NBER Working Papers No. 18673, Cambridge, MA: National Bureau of Economic Research.

Guo, Z., Wang, F. and Cai, Y. (2014), Low Fertility and Population Sustainable Development in China, Beijing: China Social Sciences Press.

Huang, P. (2002), Development or involution? Eighteenth-century Britain and China: A review of Kenneth Pomeranz's 'The Great Divergence: China, Europe, and the making of the modern world economy', Historical Research (4): 149-76. doi.org/10.2307/2700299.

International Labour Organization (ILO) (2017), Key Indicators of the Labour Market (KILM), Geneva: ILO. Available from: www.ilo.org/ilostat/.

International Monetary Fund (IMF) (2006), Asia rising: Patterns of economic development and growth, in World Economic Outlook, September, Washington, DC: IMF.

Jones, C. (2002), Sources of US economic growth in a world of ideas, The American Economic Review 92(1): 220-39. doi.org/10.1257/000282802760015685.

Krugman, P. (2013), Hitting China's wall, The New York Times, 18 July.

Kuijs, L. (2010), China through 2020: A macroeconomic scenario, World Bank China Research Working Paper No. 9, Washington, DC: The World Bank.

Kuznets, S. (1957), Quantitative aspects of the economic growth of nations II: Industrial distribution of national product and labor force, Economic Development and Cultural Change 5(Supplement): 3-110. doi.org/10.1086/449740.

Lewis, A. (1954), Economic development with unlimited supplies of labor, The Manchester School 22(2): 139-91. doi.org/10.1111/j.1467-9957.1954. tb00021.x. 
McMillan, M. S. and Rodrik, D. (2011), Globalization, structural change and productivity growth, NBER Working Papers No. 17143, Cambridge, MA: National Bureau of Economic Research.

National Bureau of Statistics (NBS) (various years), China Statistics Yearbook, Beijing: China Statistics Press.

National Bureau of Statistics (NBS) (2016), China: Tabulation of $1 \%$ population sampling survey data, 2015, Beijing: China Statistics Press.

Notestein, F. W. (1945), Population: The long view, in T. W. Schultz (ed.), Food for the World, Chicago: University of Chicago Press.

Rawski, T. and Mead, R. (1998), On the trail of China's phantom farmers, World Development 26(5): 767-81. doi.org/10.1016/S0305-750X(98)00012-6.

Spence, M. and Hlatshwayo, S. (2011), The evolving structure of the American economy and the employment challenge, Working Paper, March, Maurice R. Greenberg Center for Geoeconomic Studies, New York: Council on Foreign Relations.

Srinivasan, T. N. and Bhagwati, J. (1999), Outward-orientation and development: Are revisionists right?, Economic Growth Center Discussion Papers No. 806, New Haven, CT: Yale University.

Taylor, J. R. (1993), Rural employment trends and the legacy of surplus labor, 1978-1989, in Y. Y. Kueh and R. F. Ash (eds), Economic Trends in Chinese Agriculture: The impact of post-Mao reforms, New York: Oxford University Press.

Timmer, M. P. and Szirmai, A. (2000), Productivity growth in Asian manufacturing: The structural bonus hypothesis examined, Structural Change and Economic Dynamics (11): 371-92. doi.org/10.1016/S0954-349X(00)00023-0.

United Nations (UN) (2015), World Population Prospects: The 2015 revision, DVD edn, New York: Department of Economic and Social Affairs, Population Division.

Wang, F. and Mason, A. (2008), The demographic factor in China's transition, in L. Brandt and T. G. Rawski (eds), China's Great Economic Transformation, Cambridge: Cambridge University Press.

Whalley, J. and Zhao, X. (2010), The contribution of human capital to China's economic growth, NBER Working Papers No. 16592, Cambridge, MA: National Bureau of Economic Research.

Williamson, J. (1997), Growth, distribution and demography: Some lessons from history, NBER Working Papers No. 6244, Cambridge, MA: National Bureau of Economic Research. 
World Bank (1998), China 2020: Development challenges in the new century, Washington, DC: The World Bank.

World Bank and International Monetary Fund (IMF) (2016), Global Monitoring Report 2015/2016: Development goals in an era of demographic change, Washington, DC: The World Bank.

Young, A. (2003), Gold into base metals: Productivity growth in the People's Republic of China during the reform period, Journal of Political Economy 111(6): 1220-61. doi.org/10.1086/378532.

Zhu, X. (2012), Understanding China's growth: Past, present, and future, Journal of Economic Perspectives 26(4): 103-24. doi.org/10.1257/jep.26.4.103. 
This text is taken from China's 40 Years of Reform and Development: 1978-2018, edited by Ross Garnaut, Ligang Song and Cai Fang, published 2018 by ANU Press, The Australian National University, Canberra, Australia.

doi.org/10.22459/CYRD.07.2018.13 